Journal of Animal and Veterinary Advances 10 (3): 286-290, 2011

ISSN: $1680-5593$

(C) Medwell Journals, 2011

\title{
Meat Consumption and Buying Behaviors of Consumers Living in Manisa City Center, Turkey
}

\author{
Bulent Ergonul \\ Department of Food Engineering, Faculty of Engineering, Muradiye Campus, \\ University of Celal Bayar, Manisa, Turkey
}

\begin{abstract}
This study presents results of the data analysis and the results of a consumer questionnaire of 41 questions into meat and meat products carried out in Manisa city center among September 2008 and May 2009. Responds of 1200 consumers from different ages, genders and jobs were analyzed. Survey showed that despite recent food tendencies and new consumption behaviors, consumers living in Manisa still prefer red meat to poultry meat and fish. Also data related to consumption frequencies of meat kinds and meat products were conducted in the study.
\end{abstract}

Key words: Meat, meat products, consumer, questionnaire, food tendencies, consumption, Turkey

\section{INTRODUCTION}

Due to the ongoing globalization of international markets, meat has become a major product among all agricultural goods with a very large of exchanges and high consumption rates, all around the world (respectively $7 \%$ and $3 \%$ share of the world trade and world demand for agricultural products) (Radman et al., 2005). Since, meat is an important source of protein, consumers should consume $100-150 \mathrm{~g}$ meat in a day to establish a healthy diet. Since, meat is a central element in the eating and the role of meat has therefore been also prominently discussed when talking about food trends (Grunert, 2006).

Animal breeding and husbandry is an important industry and mainstay in Turkey. Today, approximately 11 million cattle, 24 million sheep, 5 million goats were breaded in Turkey. Total of red meat consumption amount of Turkish people was 482 million $\mathrm{kg}$, this amount was 1.1 billion $\mathrm{kg}$ for poultry meat (Anonymous, 2009).

Conducting researches on determination of the structure of meat products consumption, tendencies of consumers in terms of animal products and reasons affecting consumer preferences are important for planning the animal breeding facilities in the near future. Also, Food Marketing Institute has documented that a majority of consumers consider taste, nutrition, product safety and price as very important factors in food selection (Roeber et al., 2009).

The culture, traditions, customs, taboos are influencing the consumption of meat, especially in Turkish society. Rather limited information is available on the meat consumption patterns of Turkish consumers. In this study, it was aimed to identify the trends in consumer lifestyles with regard to meat and to outline which those factors were or were not important in the consumer's decision making process.

\section{MATERIALS AND METHODS}

The survey process was made up of personal interviews. The questionnaire consisted of 41 questions was applied to 1200 consumers living in Manisa with different sex, age and educational level. Consumers were chosen randomly. Questions of the survey are given as in Table 1.

Consumers were asked about their buying and consumption behaviors with respect to meat products. Respondents had to evaluate, the importance of different factors taken into consideration when purchasing meat and meat products such as quality and price. Consumers were also asked to answer yes/no questions in order to determine several important factors, affecting their consumption decisions. Consumers were asked for their opinions on ISO and HACCP certificates and about the impacts of these certificates on their meat consuming habits.

Table 1: Results of the questionnarie used in the survey $(n=1200)$

\begin{tabular}{ll}
\hline Questionnarie & Percentage \\
Which meat do you prefer to consume? & 34 \\
Red meat & 22 \\
Poultry meat & 23 \\
Fish & 21 \\
All of them & 0 \\
I don't like to consume meat & \\
Why do you pr efer red meat / poultry meat /fish? & 54 \\
Tastier & 12 \\
More nutritious & 22 \\
Healthier &
\end{tabular}


Table 1: Continued

Questionnarie

Cheaper

I used to consume

Can be purchased easily

What is your priority criteria to purchase meat?

Type

Freshness

Low fat content

Cheapness

Healthiness

Which type of meat is more risky in terms of health?

Red meat

Poultry meat

Fish

Where do you purchase meat?

I hunt/I slaughter

Butcher/Fishery

Slaughter house/Fish farm

Super markets

Can buy anywhere

Which one of the following is more healthier?

Red meat

Poultry meat

Fish

Do you believe that poultry meat you consume is healthy?

Yes

No

Do you believe that red meat you consume is healthy?

Yes

No

Do you believe that fish you consume is healthy?

Yes

No

Which one of the poultry meat do you prefer to consume

Chicken

Turkey

Others

How do you purchase poultry meat?

Whole chicken/Tuekey

Thigh meat

Breast meat

How often do you consume poultry meat?

Once a month

Once a week

1-3 times in a week

3-5 times in a week

Everyday

How do you consume poultry meat?

Boiled

Fried

Cooked in oven

Grilled

Meat meal with vegetables

How do you purchase red meat?

Carcass/half carcass

Flaked

Bony (thigh, arm)

How often do you consume red meat?

Once a month

Once a week

1-3 times in a week

3-5 times in a week

Everyday

Which type of red meat do you prefer?

Beef

Lamb-sheep

Goat

All of them (type is not important)

How do you consume red meat?

Boiled

Fried

Cooked in oven
Table 1: Continued

Questionnarie

Percentage

Grilled

25

Meat meal with vegetables

35

How do you purchase fish?

Big fish (tuna fish, salmon)

33

Little fish (sardine, anchovy)

Canned fish

How do you consume fish?

Fried

Cooked in oven

Steam cooked

How often do you consume fish?

Once a month

Once a week

1-3 times in a week

3-5 times in a week

Everyday

Which one of the following has more cholesterol?

Red meat

Poultry meat

Fish

I don't know

I don't know what the cholesterol is

Do you consume offals?

Yes

No

Consuming offal is

Not healthy

Healthy

I don't know

Which offal do you prefer to consume?

Lamb/cattle liver

Chicken liver

Heart of lamb/cattle

Spleen

Kidney

Tongue

Kokorec (grilled sheep intestine)

How often do you consume offal

Everyday

Once a week

1-3 times in a week

3-5 times in a week

Once a month

Which one of the followings do you consume more?

Fermented sausage

Salami

Sausage

Pastrami

Dried meat

Doner

Meatballs and hamburger

I prefer fermented sausage/salami/sausage/doner made from

Red meat

Poultry meat

Meat kind is not important

When you purchase sausage/salami/pastrami/doner,

most influencing criteria is..

Price

Trade mark

I have no criteria

How often do you

Everyday

Once a week

1-3 times in a week

3-5 times in a week

Once a month

Once in 2 months 


\begin{tabular}{|c|c|}
\hline Questionnarie & Percentage \\
\hline \multicolumn{2}{|l|}{ How often do you consume pastrami? } \\
\hline Everyday & 1 \\
\hline Once a week & 3 \\
\hline $1-3$ times in a week & 2 \\
\hline $3-5$ times in a week & 0 \\
\hline Once a month & 13 \\
\hline Once in 2 months & 12 \\
\hline Once a year & 69 \\
\hline \multicolumn{2}{|l|}{ How often do you consume sausage/salami? } \\
\hline Everyday & 3 \\
\hline Once a week & 26 \\
\hline $1-3$ times in a week & 13 \\
\hline $3-5$ times in a week & 6 \\
\hline Once a month & 23 \\
\hline Once in 2 months & 29 \\
\hline \multicolumn{2}{|l|}{ How often do you consume doner? } \\
\hline Everyday & 2 \\
\hline Once a week & 26 \\
\hline $1-3$ times in a week & 12 \\
\hline $3-5$ times in a week & 4 \\
\hline Once a month & 37 \\
\hline Once in 2 months & 19 \\
\hline \multicolumn{2}{|l|}{ How do you pur chase meatballs? } \\
\hline I purchase minced meat and prepare meatballs at my kitchen & 90 \\
\hline I purchase cooked meatballs & 10 \\
\hline \multicolumn{2}{|l|}{$\begin{array}{l}\text { Do you believe that lowering the amount of red meat in } \\
\text { diet is important for a healthy life? }\end{array}$} \\
\hline Yes & 58 \\
\hline I do not know & 19 \\
\hline No & 23 \\
\hline \multicolumn{2}{|l|}{ Did you ever try soyfoods instead of meat? } \\
\hline Yes & 13 \\
\hline No & 85 \\
\hline I prefer soymeat instead of meat & 1 \\
\hline I tried once but I did not like & 1 \\
\hline \multicolumn{2}{|l|}{$\begin{array}{l}\text { Did mad-cow disease make a negatory affect } \\
\text { on your red-meat consumption? }\end{array}$} \\
\hline Yes & 63 \\
\hline No & 37 \\
\hline \multicolumn{2}{|l|}{$\begin{array}{l}\text { Did bird-flu disease make a negatory affect } \\
\text { on your meat consumption? }\end{array}$} \\
\hline Yes & 72 \\
\hline No & 28 \\
\hline \multicolumn{2}{|l|}{ Have you ever heard about the HACCP system } \\
\hline Yes, I only heard about it & 18 \\
\hline I know the concept of the system & 28 \\
\hline No & 54 \\
\hline \multicolumn{2}{|l|}{$\begin{array}{l}\text { While purchasing a food, do you check whether } \\
\text { the manufacturer has HACCP certification or not? }\end{array}$} \\
\hline Yes & 18 \\
\hline No & 82 \\
\hline \multicolumn{2}{|l|}{ Have you ever heard about the ISO quality system? } \\
\hline Yes, I only heard about it & 32 \\
\hline I know the concept of the sy stem & 62 \\
\hline No & 6 \\
\hline \multicolumn{2}{|l|}{$\begin{array}{l}\text { While purchasing a food, do you check whether } \\
\text { the manufacturer has ISO quality system certification or not? }\end{array}$} \\
\hline Yes & 49 \\
\hline No & 51 \\
\hline
\end{tabular}

\section{RESULTS AND DISCUSSION}

Behavior of meat and meat products consumers was studied with the purpose to find out the real structure of meat and meat products consumption (that is to say the actual consumption of these commodities) as well as the purchasing frequency. Demographical characteristics of the consumers who were attended to the questionnaire were shown as Table 2. As shown from the Table 2, it was
Table 2: Demographical characteristics of respondents $(n=1200)$

\begin{tabular}{ll}
\hline Characteristics & Values \\
\hline Gender & \\
Male & $613(51.1 \%)$ \\
Female & $587(48.9 \%)$ \\
Marital status & \\
Married & $500(41.7 \%)$ \\
Single & $700(58.3 \%)$ \\
Age & \\
$<20$ & $115(9.6 \%)$ \\
$20-30$ & $633(52.7 \%)$ \\
$30-40$ & $239(19.9 \%)$ \\
$40-50$ & $140(11.7 \%)$ \\
$>50$ & $73(6.1 \%)$ \\
Educational status & \\
Primary school & $135(11.3 \%)$ \\
High school & $241(20.1 \%)$ \\
University & $802(66.8 \%)$ \\
Master and PhD & $22(1.8 \%)$ \\
\hline
\end{tabular}

aimed to interview with equal numbers of male and female respondents. Number of male and female consumers were $613(51.1 \%)$ and $587(48.9 \%)$, respectively. About 500 $(41.7 \%)$ of the respondents declared that their marital status was married and approximately $58.3 \%$ of the consumers were single.

About $9.6 \%$ of the respondents were under the age of 20 whereas, nearly the half $(52.7 \%)$ of the respondents ages were among 20 and 30. Ages of 239 (19.9\%) consumers were among 30 and 40 . About $66.8 \%$ of the respondents were university graduates whereas, 135 of them $(11.3 \%)$ were primary school graduates.

Results of the survey were shows as Table 2. As shown from the Table 1, red meat (34\%) is the most preferred meat in the region. Red meat is followed by fish $(23 \%)$ and poultry meat $(22 \%) .21 \%$ of the consumers revealed that the type of the meat was not important. It is obvious that $45 \%$ of the consumers prefer white meat than the red meat.

Main reason of the preference of any meat to others is its taste $(54 \%)$. Second criterion affecting the choice of the consumer is the health concern $(22 \%)$. Also, the priority criterion of the consumers while purchasing meat was stated as freshness $(45 \%)$. Healthiness is another factor, affecting the choice of the consumer while purchasing (26\%). Consumers believe that fish meat is the healthiest one among all meat types (71\%).

When it comes to health, consumers find red meat is more risky than the others in terms of consumer health $(74 \%)$. Consumers are thinking that consuming red meat affects the health adversely. In spite of that they still prefer consuming red meat (34\%).

Consumers purchase meat generally from butchers ( $43 \%$ ) and supermarkets $(42 \%)$, only $1 \%$ of them purchase their meat from slaughter houses or fish farms. Results are not surprising because it is known that there is a current trend to shop in super and hyper markets. Most of the consumers believe that poultry meat, they consume is healthy $(82 \%)$. Also, they declare that red meat and fish, they consume are found healthy (76 and $86 \%$, 
respectively). About $94 \%$ of the consumers prefer chicken meat than the other poultry meat kinds. About $37 \%$ of the consumers prefer chicken thigh whereas, 35\% of consumers prefer purchasing whole chicken and $28 \%$ prefer breast meat. About $42 \%$ of the consumers consume poultry meat once a week whereas, only $1 \%$ of them consume everyday.

Consumers generally cook their poultry meat in oven (29\%) or they prefer frying $(27 \%)$. About $12 \%$ of them consume poultry meat in a vegetable meal. In questionnaire, it was asked to consumers that how did they prefer to purchase red meat. About $84 \%$ of the consumers revealed that they preferred to purchase flaked red meat. About $12 \%$ of the consumers prefer bony (thigh or arm) meat whereas, $4 \%$ of them prefers to purchase carcass or half carcass. Consumers purchasing carcass, declare that they cut carcass at kitchen and stored at their freezers until cooking.

About $35 \%$ of the consumers, consume red meat once a week, on the other hand, $33 \%$ of them consume red meat only once a month and $24 \%$ consume 1-3 times a week. Only $3 \%$ of the consumers, consume red meat everyday. When the high prices of red meat in Turkey are taken into account, answers are not surprising. Consumers in Turkey can not purchase red meat whenever they want. For a well established healthy diet and for consuming high quality protein, consumers should eat approximately $100-150 \mathrm{~g}$ red meat day ${ }^{-1}$. It is obvious that, high cost of red meat also affects the diet adversely.

About $60 \%$ of the consumers prefer beef as red meat whereas, the $27 \%$ prefer lamb or sheep. Consumers in Manisa, prefer eating red meat in vegetable meals (35\%). Also, $25 \%$ of them consume red meat after grilling. About $63 \%$ of the consumers prefer purchasing little fish like sardine or anchovy whereas, $33 \%$ of them prefer big fish like tuna or salmon. Only $4 \%$ of the group prefers buying canned fish. Consumers in Manisa generally cook their fish by frying in pan $(60 \%)$ or in oven $(30 \%)$.

Steam cooking method which is known as the healthiest way of fish cooking is preferred by only $10 \%$ of the consumers. In steam cooking, there is no additive oil is used. Most of the people interviewed, consume fish once a month $(44 \%)$ or once a week $(42 \%)$. No one declared that they were eating fish everyday. Although, red meat is generally preferred and consumed in Manisa, nearly all of the consumers know that red meat has the highest cholesterol content than poultry meat or fish $(90 \%)$. About $1 \%$ of the consumers declared that they did not hear anything about the term cholesterol. It is seen that $6 \%$ of the consumers do not have any idea about the cholesterol levels of meat kinds. Anout $51 \%$ of the consumers interviewed purchase offal. But, it is found surprising that $60 \%$ of the consumers declare that offal is not healthy in terms of consumer health. Lamb or cattle liver (31\%) and kokorec ( $31 \%$ ) are the most preferred offal among the others given in questionnaire. Kokorec is a traditional offal product, widely consumed in all regions of Turkey. It is also known as grilled sheep intestine.

There is no national standard established for kokorec in Turkish Food Standards. Because of the manufacturing technique and the hygienic concerns on raw material, kokorec is not found suitable in terms of food safety and consumer health. On the other hand, selling kokorec is not restricted in any region of Turkey.

About $71 \%$ of the consumers purchase and consume offal once a month whereas, $20 \%$ of the people interviewed purchase offal once a week.

Fermented sausage is the most preferred processed meat product $(43 \%)$ among sausage, salami, pastrami, dried meat, doner and meatballs and hamburger. Turkish type fermented sausage (sucuk or soudjouck) is one of the most known and consumed traditional meat product in Turkey (Kundakci et al., 2007). When compared to other fermented sausages consumed in many countries of the world, sucuk is more spicy, dry and aromatic because of garlic used in formulation.

Only $2 \%$ of the respondents prefer consuming pastrami. About $1 \%$ of them consume pastrami everyday. Since, pastrami is made from valuable meat parts (like L. dorsi) of the carcass (Kilic, 2009), it is found too expensive by the consumers. About $69 \%$ of the consumers can purchase pastrami only once a year. On the other hand, Turkish fermented sausage (sucuk) is consumed by consumers at least once a week (34\%). About $5 \%$ of the consumers purchase sucuk everyday. Respondents interviewed prefer meat products manufactured from red meat (cattle or lamb) (72\%). For $12 \%$ of the consumers meat kind is not important they declare that they can consume meat products manufactured by using both red or poultry meat.

It is determined that trade mark significantly influences consumers decisions on purchasing processed meat products $(69 \%)$. Respondents generally, purchase meat products which they always used to consume. Sausage and salami are cheaper meat products when compared to fermented sausage. About $26 \%$ of the consumers purchase salami and sausage once a week whereas, $6 \%$ of them consume 3-5 times a week. Doner which has been known by some other names like gyro, doner-kebap, dona-kebab, chawarma or shawirma is a traditional middle Eastern meat product widely consumed in many countries of the world (Ergonul and Kundakci, 2007). Doner kebap slices are served to consumer either on a plate or on bread in many buffets and restaurants (Kayisoglu et al., 2003). Also, sliced doner meat is widely sold in packaged polystyrene plates in supermarkets and butchers. About 26\% of the respondents, declare that they consume doner once a week whereas, $37 \%$ of the consumers prefer to consume döner only once a month. 
It is thought that, altough this product can be easily purchased from markets, consumers find it expensive to consume frequently.

One of the most popular and widely consumed meat products in Turkey is meatball (kofte). Traditional Turkish kofte is also known as kasap kofte (butchers kofte). For manufacturing Turkish kofte, bread moisturized by tap water and added into kofte dough. Also, onion and egg are added into formulation. Turkish people find traditional kofte more preferable than the others. As seen from the respondent answers, 90\% of them purchase minced meat and prepares their own kofte at their kitchens. Only $10 \%$ of them purchase cooked (ready to eat) kofte from markets in their packages.

Although, about $34 \%$ of the consumers in Manisa, prefer red meat to others they believe that lowering the amount of red meat in diet is important in terms of establishing a healthy diet and healthy life. About 19\% of the respondents declare that they do not know about the importance of red meat amount in a diet. Soy meat alternatives, also called meat analogs are made primarily from soy proteins, wheat gluten and may contain carbohydrates (Anonymous, 2009). Soy meat alternatives are made specifically to resemble meats, poultry or fish products in taste, texture, color and form. We asked to respondents for their opinions about soy meat.

About $85 \%$ of the respondents declare that they do not prefer meat analogs instead of consuming meat. About $1 \%$ of the consumers declare that they regularly use soy meat in their diet.

In the past decade, two important diseases mad-cow disease and bird-flu significantly influenced the meat purchasing and consuming habits of consumers all over the world. About $63 \%$ of the respondents living in Manisa agree that mad-cow disease affected their meat consuming habits and they did not consume red meat at that period. Also, $72 \%$ of the consumers stopped consuming poultry meat in 2006 because of bird-flu disease. The HACCP system which is science based and systematic, identifies specific hazards and measures for their control to ensure, the safety of food and consumer health (Anonymous, 2008). It is a big concern that consumers really prefer products having HACCP label or not. $54 \%$ of the 1200 respondents declare that they did not hear anything about the HACCP system and its importance in food safety. About $28 \%$ of the consumers know the concept of the system whereas, $18 \%$ of the respondents heard only the name HACCP. It is concerning that $82 \%$ of the respondents do not control whether a meat product has HACCP label or not. When compared to HACCP is O Quality System is rather familiar to respondents. About $62 \%$ of them know the concept of ISO and approximately half of the respondents $(49 \%)$ check whether a meat product has ISO label on its package or not.

\section{CONCLUSION}

According to findings of the questionnaire, red meat is still preferred by most of the respondents. Although, they know cholesterol content of red meat is higher than poultry meat or fish, consumers living in Manisa, prefer processed meat products manufactured from red meat. Meat is bought generally from butchers or supermarkets and the priority criteria taken into account while purchasing meat was freshness. Red meat is usually consumed as meat meal (with vegetables) whereas poultry meat is consumed after frying or cooked in oven.

Nearly, half of the consumers prefer consuming offal and they know that consuming offal is not healthy. Most of the respondents prefer consuming liver or kokorec. Respondents declare that diseases in the past decade, significantly affected their meat consumption habits adversely. They have concerns on food safety but, half of them did not hear anything about the system HACCP and most of them do not control the packages whether they have HACCP label or not. It is obvious that consumers should be conscious about the food safety systems.

\section{REFERENCES}

Anonymous, 2008. http://www.fao.org/docrep/005/ y1579e/y1579e03.htm.

Anonymous, 2009. http://www.soyfoods.org/products/ soy-fact-sheets/soy-meat-alternative-fact-sheet.

Ergonul, B. and A. Kundakci, 2007. Changes in quality attributes of Turkey doner during frozen storage. J. Muscle Foods, 18: 285-293.

Grunert, K.G., 2006. Future trends and consumer lifestyles with regard to meat consumption. Meat Sci., 74: 149-160.

Kayisoglu, S., I. Yilmaz, M. Demirci and H. Yetim, 2003. Chemical composition and microbiological quality of the Doner Kebabs in Tekirdag market. Food Control, 14: 469-474.

Kundakci, A., A. Kayacier and B. Ergonul, 2007. The effect of starter culture and packaging on the chemical, microbiological and sensory quality of Turkish soudjouk. Int. J. Food Propert., 10: 537-547.

Kilic, B., 2009. Current trends in traditional Turkish meat products and cuisine. LWT-Food Sci. Technol., 42: $1581-1589$.

Radman, M., L. Camanzi and A. Kolega, 2005. Preferences and buying behaviour of beef consumers in Tuscany. J. Central Eur. Agric., 6: 99-106.

Roeber, D.L., J.A. Scanga, K.E. Belk and G.C. Smith, 2009. Consumer attitudes and pereferences. Anim. Sci., 2009: 45-47. 